\title{
Performance of Dye-Sensitized Solar Cells with (PVDF-HFP)-KI-EC-PC Electrolyte and Different Dye Materials
}

\author{
M. M. Noor, ${ }^{1,2}$ M. H. Buraidah, ${ }^{2}$ S. N. F. Yusuf, ${ }^{2}$ M. A. Careem, ${ }^{3}$ S. R. Majid, ${ }^{2}$ and A. K. Arof ${ }^{2}$ \\ ${ }^{1}$ Centre for Foundation Studies, International Islamic University Malaysia, Jalan Universiti, 46350 Petaling Jaya, Selangor, Malaysia \\ ${ }^{2}$ Department of Physics, Centre for Ionics University Malaya, University of Malaya, 50603 Kuala Lumpur, Malaysia \\ ${ }^{3}$ Department of Physics, University of Peradeniya, 20400 Peradeniya, Sri Lanka
}

Correspondence should be addressed to A. K. Arof, akarof@um.edu.my

Received 8 July 2011; Revised 20 September 2011; Accepted 20 September 2011

Academic Editor: Leonardo Palmisano

Copyright (c) 2011 M. M. Noor et al. This is an open access article distributed under the Creative Commons Attribution License, which permits unrestricted use, distribution, and reproduction in any medium, provided the original work is properly cited.

\begin{abstract}
A plasticized polymer electrolyte system composed of PVDF-HFP, potassium iodide (KI), and equal weight of ethylene carbonate (EC) and propylene carbonate (PC) has been used in a dye-sensitized solar cell (DSSC). The electrolyte with the composition 40 wt. $\%$ PVDF-HFP-10 wt. \% KI-50 wt. \% (EC + PC) exhibits the highest room temperature ionic conductivity of $1.10 \times 10^{-3} \mathrm{~S} \mathrm{~cm}^{-1}$. A small amount of iodine crystal of about $10 \mathrm{wt}$. \% of KI was added to the electrolyte in the liquid state to provide the redox couple for DSSC operation. The polymer electrolyte films were prepared by the solvent casting method. The DSSCs were fabricated with the electrolyte film sandwiched between a $\mathrm{TiO}_{2} /$ dye photoelectrode and a Pt-counter electrode and characterized under $100 \mathrm{~mW} \mathrm{~cm}^{-2}$ white light. The DSSC performance with different dyes such as Ruthenizer 535 (N3), anthocyanin, chlorophyll, and a mixture of anthocyanin and chlorophyll $(\mathrm{v} / \mathrm{v}=1)$ has been compared. The DSSC with Ruthenizer $535(\mathrm{~N} 3)$ dye exhibits the best performance with a short-circuit current density of $8.16 \mathrm{~mA} \mathrm{~cm}^{-2}$, open-circuit voltage of $0.76 \mathrm{~V}$, fill factor of 0.35 , and photoconversion efficiency of $2.2 \%$.
\end{abstract}

\section{Introduction}

Solar cells are devices that utilize energy from the sun by converting solar radiation directly into electricity. The conventional solar cell device is silicon-based solar cells with efficiency as high as 30\% under concentrated light. However, high manufacturing cost prevents the widespread use of silicon cells $[1,2]$. Dye-sensitized solar cells (DSSCs) have attracted much attention as they can also offer high-energy conversion efficiencies. DSSCs are easy to fabricate, and manufacturing cost is lower compared to silicon solar cells [3-5]. The structure of the DSSC consists of $\mathrm{a} \mathrm{TiO}_{2}$ photoelectrode coated on conducting glass, dye sensitizer, an electrolyte containing redox couple, and a counter electrode [6]. Energy conversion in a DSSC is based on the injection of an electron from a photoexcited state of the dye into the conduction band of the $\mathrm{TiO}_{2}$ photoelectrode [7]. Since the dye plays an important role in harvesting light and solar energy conversion to electricity, efforts have been focused on dye materials. The commercial synthetic ruthenium (II) polypyridyl complexes such as N719 and N3 are widely used in DSSCs due to the satisfactory photoelectric conversion efficiency up to $10 \%[8,9]$. However, these dyes use metal compound complexes, which are expensive and produce environmental pollution [10]. Another approach is to use natural dyes, which is environmentally friendly, nontoxic, biodegradable, and cheaper compared to the synthetic dyes, but has yet to show good performance in terms of efficiency [11]. Natural sensitizing dyes include anthocyanins $[12,13]$. In this study, the DSSCs were prepared with N3 dye or natural dyes. Anthocyanin from black rice extraction was used as the dye since anthocyanin has good chemical bonding with titanium dioxide [14]. Chlorophyll, a natural photosensitizer for photosynthesis in green plants, is another attractive potential compound as photosensitizer in the visible region for DSSC $[15,16]$.

\section{Experimental}

2.1. Materials. Poly(vinylidenefluoride-hexafluoropropylene) (PVDF-HFP) of MW 400.000 and potassium iodide (KI) salt were procured from Aldrich. High-purity (99\%) 
TABLE 1: Different compositions of PVDF-HFP polymer electrolyte.

\begin{tabular}{|c|c|c|c|c|c|}
\hline \multicolumn{2}{|c|}{ Electrolyte composition in wt.\% ratio } & \multirow[b]{2}{*}{ PVDF-HFP } & \multicolumn{2}{|c|}{ Weight (g) } & \multirow{2}{*}{$\begin{array}{l}\text { Iodine }(\mathrm{g}) \\
(10 \% \text { of } \mathrm{KI})\end{array}$} \\
\hline Sample & $(\mathrm{PVDF}-\mathrm{HFP}: \mathrm{KI}):(\mathrm{EC} / \mathrm{PC})$ & & KI & $\mathrm{EC} / \mathrm{PC}$ & \\
\hline S0 & $(50: 0): 50$ & 1.00 & 0.00 & 1.00 & 0.00 \\
\hline S1 & $(45: 5): 50$ & 0.90 & 0.10 & 1.00 & 0.01 \\
\hline S2 & $(40: 10): 50$ & 0.80 & 0.20 & 1.00 & 0.02 \\
\hline S3 & $(35: 15): 50$ & 0.70 & 0.30 & 1.00 & 0.03 \\
\hline S4 & $(30: 20): 50$ & 0.60 & 0.40 & 1.00 & 0.04 \\
\hline
\end{tabular}

acetone, ethylene carbonate (EC), and propylene carbonate (PC) were purchased from Fluka and $\mathrm{TiO}_{2}$ paste PST-18NR from JGC Catalyst and Chemicals Ltd., Japan. Compact layer solution, di-isopropoxytitanbis(acetylacetonate) was purchased from Aldrich and was diluted with ethanol to obtain 0.38 M. Ruthenizer 535 (N3) dye, purchased from Solaronix, Switzerland was diluted to $0.003 \mathrm{M}$ with ethanol and chloroplatinic acid was diluted to $0.005 \mathrm{M}$ in 2-propanol prior to use. The chloroplatinic acid was purchased from Aldrich.

2.2. Preparation of Polymer Electrolytes. The electrolyte system using PVDF-HFP as polymer host, potassium iodide (KI) salt, and a mixture of ethylene carbonate (EC) and propylene carbonate $(\mathrm{PC})$ at $1: 1$ weight ratio as plasticizers has been prepared for application in DSSC. Several compositions by weight $\%$ ratio of (polymer:salt): (plasticizer) were prepared as listed in Table 1 . Acetone was used to dissolve the polymer, salt, and the plasticizer at $40^{\circ} \mathrm{C}$, and the liquid solutions were cast to form electrolyte films. Electrochemical impedance spectroscopy (EIS) technique was used to determine the conductivity of each composition. The highest conducting electrolyte was used to fabricate the DSSC.

2.3. Preparation of Dye Materials. Three types of dyes were prepared for this study. First, chlorophyll dye was prepared from $20 \mathrm{~g}$ fresh leaves of fragrant screwpine (Pandanus amaryllifolius) or locally known as pandan leaves. The leaves were cleaned with distilled water, rinsed with ethanol, and were cut into small pieces and immersed in $200 \mathrm{~mL}$ ethanol. Second, anthocyanin dye solution was prepared from $100 \mathrm{~g}$ black rice immersed in $100 \mathrm{~mL}$ ethanol. Both solutions were kept for 24 hours in the dark before filtration to remove residues. Third, to obtain $0.003 \mathrm{M} \mathrm{N} 3$ dye, $10 \mathrm{mg}$ Ruthenizer 535 (N3) dye powder was diluted in $5 \mathrm{~mL}$ ethanol and kept for 24 hours in the dark before use.

2.4. Preparation of Electrodes. The working electrode is a $\mathrm{TiO}_{2}$ layer, and the counter electrode is a platinum layer. Indium tin oxide (ITO) glass was used as a substrate for both electrodes. To prepare the working electrode or photoanode, $\mathrm{TiO}_{2}$ paste was doctor bladed on the ITO surface [1719]. Prior to this, the ITO glass has been spin-coated with diisopropoxytitanium bis(acetylacetonate) at $3000 \mathrm{rpm}$ for 10 seconds to improve adhesion of $\mathrm{TiO}_{2}$ on the ITO glass and provide a larger $\mathrm{TiO}_{2} / \mathrm{ITO}$ contact area. This compact layer also minimizes contact between the redox electrolyte and the conductive ITO surface. This is necessary to prevent electron recombination in the DSSC and hence improve efficiency [20]. The layers were sintered at $450^{\circ} \mathrm{C}$ for 30 minutes after each process. The prepared $\mathrm{TiO}_{2}$ electrode was immersed in each dye solution and left for 24 hours in the dark to allow the dye to attach to the $\mathrm{TiO}_{2}$ surface. The $\mathrm{TiO}_{2} /$ dye electrode was washed in ethanol and dried before assembling the DSSC. The counter electrode was prepared by spin coating a thin layer of platinum $(\mathrm{Pt})$ solution (chloroplatinic acid diluted to $0.005 \mathrm{M}$ in 2-propanol) on the conducting surface of a cleaned ITO glass and sintered at $450^{\circ} \mathrm{C}$ for 30 minutes [21]. In this study, DSSCs were illuminated from the Pt counter electrode side. Hence the prepared Pt counter electrode should be highly transparent.

2.5. Preparation of DSSCs. The DSSCs were prepared using a photoelectrode with $0.16 \mathrm{~cm}^{2}$ working area, a counter electrode of Pt-coated ITO glass, and an electrolyte film containing (PVDF-HFP), KI, a mixture of EC/PC plasticizer, and a small amount of iodine. The DSSCs were fabricated by sandwiching the electrolyte between the $\mathrm{TiO}_{2}$ and Pt electrodes.

2.6. Characterization and Measurements. For the polymer electrolytes, electrochemical impedance spectroscopy (EIS) technique was used to determine the highest conducting composition. The impedance of the samples was measured using the HIOKI 3520 LCR Hi-Tester interfaced to a computer with frequency ranging from $50 \mathrm{~Hz}$ to $100 \mathrm{kHz}$ at room temperature. Each sample was sandwiched between two stainless steel electrodes of diameter $2.0 \mathrm{~cm}$ before performing the measurement. The conductivity was calculated using equation

$$
\sigma=\frac{l}{R_{B} A} .
$$

Here $R_{B}$ is the bulk resistance taken at the intersection of the Nyquist plot with the real impedance axis, $l$ is the film thickness, and $A$ is the surface area of the electrode/electrolyte contact. The absorption spectrum of the different dyes was taken with Shimadzu UV-1650PC UV-vis spectrophotometer. The photocurrent-voltage $(\mathrm{I}-\mathrm{V})$ characteristics of the DSSCs were measured under illumination from a xenon lamp at the intensity of $100 \mathrm{Mw} \mathrm{cm}^{-2}$ using a Keithley 2400 electro meter. The fill factor (FF) was calculated using the equation

$$
\mathrm{FF}=\frac{I_{\max } V_{\max }}{I_{\mathrm{SC}} V_{\mathrm{OC}}}
$$




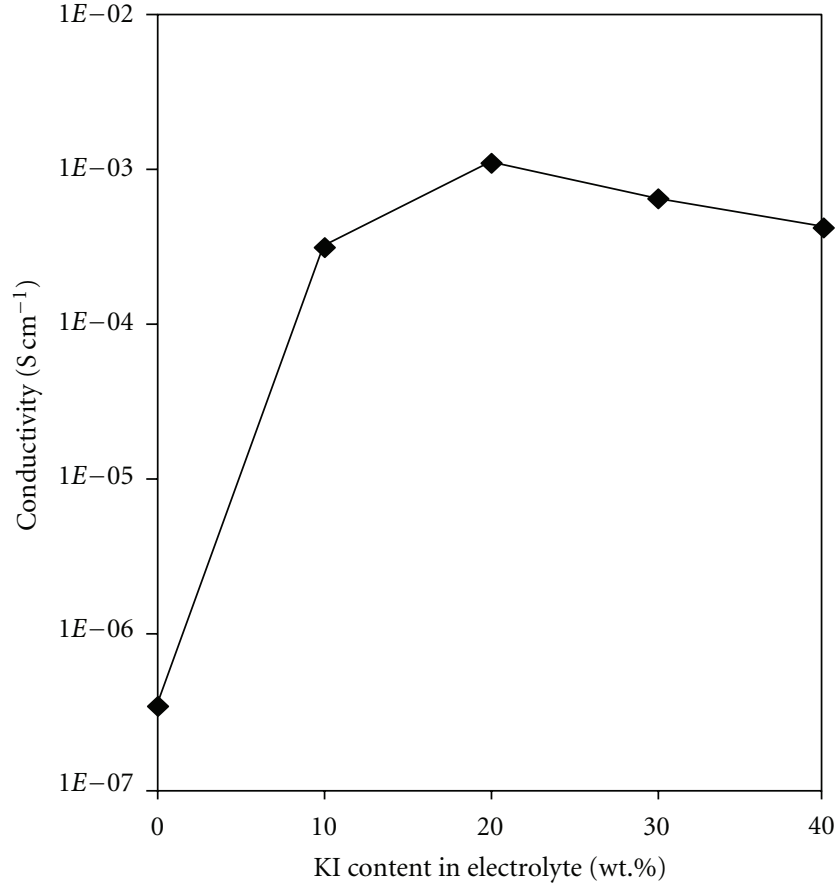

FIGURe 1: Conductivity of PVDF-HFP electrolyte with different salt contents.

where $I_{\max }$ and $V_{\max }$ are the maximum output value of current and voltage, respectively, and $I_{\mathrm{SC}}$ and $V_{\mathrm{OC}}$ are the short-circuit current and open-circuit voltage, respectively. The total energy conversion efficiency was calculated using the equation

$$
\eta=\frac{I_{\mathrm{SC}} V_{\mathrm{OC}} \times \mathrm{FF}}{P_{\text {in }}},
$$

where $P_{\text {in }}$ is the power of incident light.

\section{Results and Discussion}

3.1. EIS of Polymer Electrolytes. The plot of room temperature conductivity of the electrolyte as a function of salt content is shown in Figure 1. The conductivity increases with the salt concentration, reaching a maximum value of $1.10 \times$ $10^{-3} \mathrm{~S} \mathrm{~cm}^{-1}$ at $20 \mathrm{wt}$ \% salt and gradually decreases thereafter. Conductivity increase is due to the increase of charge carriers or mobile ions when the salt content was increased. At high salt concentration, the distance between dissociated ions may become too close to each other enabling them to recombine into neutral ion-pairs which do not contribute to conductivity. Such phenomenon has been reported in the literature [22-24] and can be proven through Fourier transform impedance spectroscopy. The use of $50 \mathrm{wt}$. \% EC/PC as plasticizers in the electrolyte helps to promote ion transfer and ion dissociation that enhances the conductivity. It is reported that the addition of plasticizers (up to $50 \mathrm{wt} . \%$ ) enhances conductivity without compromising thermal, electrochemical, and dimensional stability of the electrolyte and the most employed plasticizers are low-molecular-weight

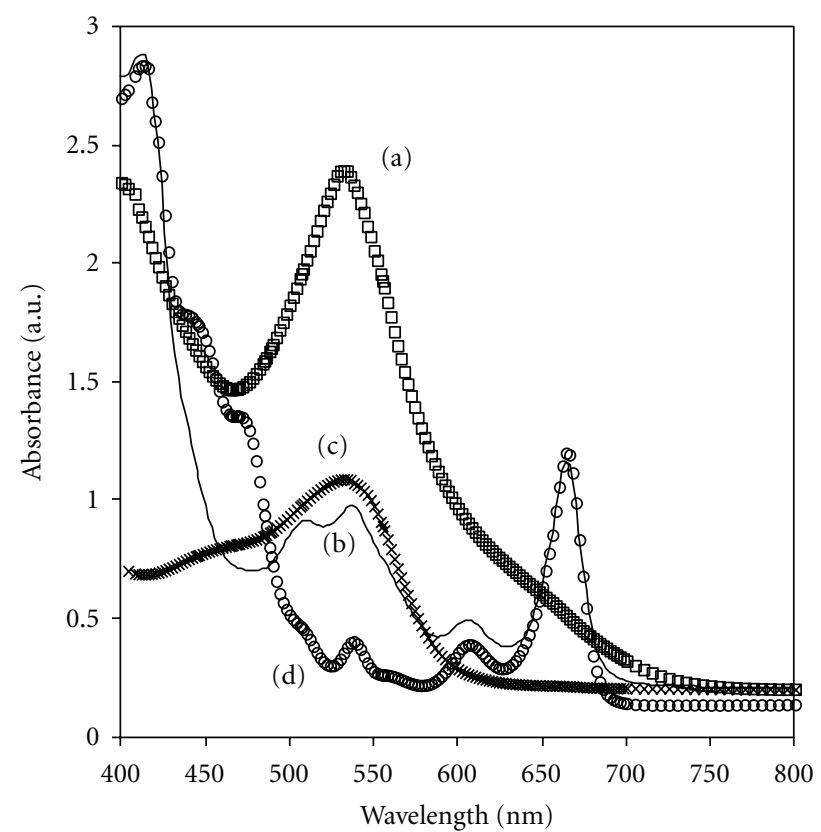

Figure 2: Absorption spectra of different dye materials. (a) Ruthenizer 535 (N3), (b) anthocyanin/chlorophyll mixture, (c) anthocyanin, (d) chlorophyll.

organic solvents such as propylene carbonate (PC) and ethylene carbonate (EC) $[25,26]$.

3.2. Characterizations of Natural Dye Sensitizers. Figure 2 shows the absorption spectra of Ruthenizer 535 (N3), anthocyanin, chlorophyll and a mixture of anthocyanin and chlorophyll, sensitizers at 1:1 volume ratio. The N3 dye exhibits maximum absorption at $535 \mathrm{~nm}$, anthocyanin from black rice extraction at $532 \mathrm{~nm}$, chlorophyll at 413 and $665 \mathrm{~nm}$, and the mixture of black-rice and chlorophyll shows maximum peaks at 413,536 , and $665 \mathrm{~nm}$. Since the sun's spectrum peaks at $550 \mathrm{~nm}, \mathrm{~N} 3$ and anthocyanin dyes should be able to absorb maximum sunlight and yield higher possibility of light harvesting [14]. Chlorophylls, which act as an effective photosensitizer in photosynthesis of green plant, has absorption maximum at $670 \mathrm{~nm}$, thus, it is an attractive potential compound as a photosensitizer in the visible region [16]. It is also found that more absorption peaks are found when two natural dyes are mixed which shows that the absorption range is enhanced. This indicates the possibility of increasing the photoelectric conversion efficiency of a dyesensitized solar cell with mixed dyes [27].

3.3. Characterizations of DSSCs. The photocurrent densityvoltage graphs for DSSCs with different dyes material are shown in Figure 3. The values of open-circuit voltage $\left(V_{\mathrm{OC}}\right)$, short-circuit current density $\left(J_{\mathrm{SC}}\right)$, fill factor $(\mathrm{FF})$, and conversion efficiency $(\eta)$ obtained from Figure 3 are summarized in Table 2. Compared to the natural dye sensitizers, DSSC with Ruthenizer 535 (N3) dye shows the best overall performance with the short-circuit current density of $8.16 \mathrm{~mA} \mathrm{~cm}^{-2}$, open-circuit voltage of $0.76 \mathrm{~V}$, fill factor of 
TABLE 2: The performance parameters of DSSCs with different dyes.

\begin{tabular}{lcccc}
\hline & $\mathrm{N} 3$ & Anthocyanin & Chlorophyll & Anthocyanin + Chlorophyll \\
\hline$J_{\text {sc }}\left(\mathrm{mA} \mathrm{cm}^{-2}\right)$ & 8.16 & 3.02 & 1.61 & 3.26 \\
$V_{\text {oc }}(\mathrm{V})$ & 0.76 & 0.36 & 0.36 & 0.36 \\
FF & 0.35 & 0.34 & 0.41 & 0.36 \\
Efficiency $(\%)$ & 2.17 & 0.37 & 0.24 & 0.42 \\
\hline
\end{tabular}

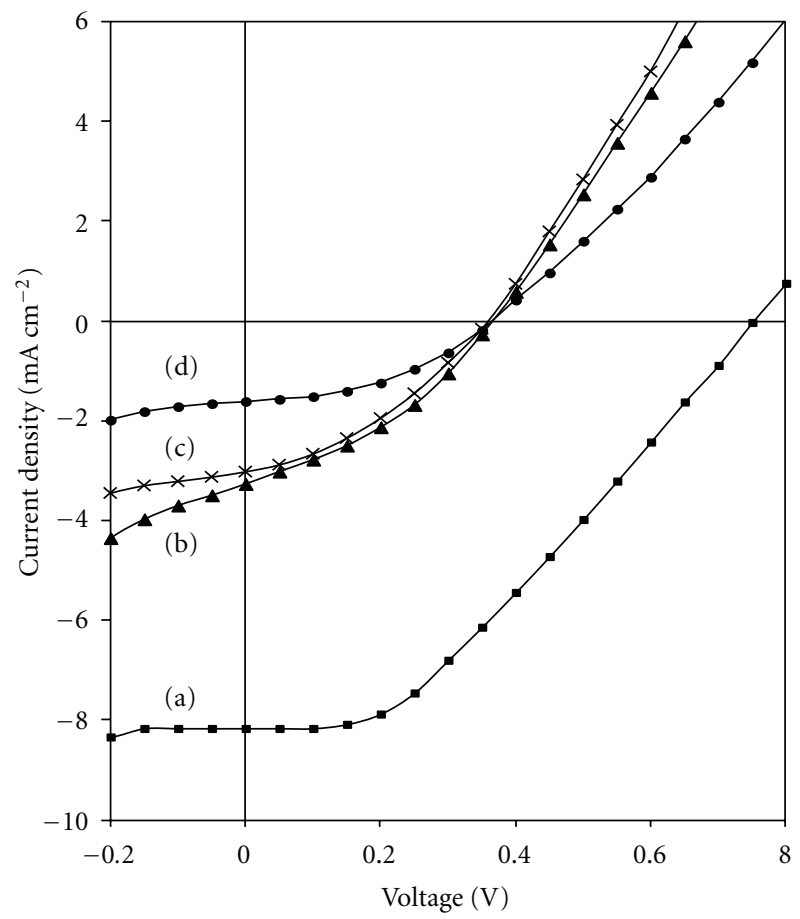

Figure 3: $J-V$ curves for DSSCs with different dye materials. (a) Ruthenizer 535 (N3), (b) anthocyanin/chlorophyll mixture, (c) anthocyanin, (d) chlorophyll.

0.35 , and photoconversion efficiency of $2.2 \%$. For natural dyes, the mixed dye system shows better efficiency than dyes prepared using individual chlorophyll or anthocyanin extract. This suggests the possibility of utilizing multinatural-dye mixture of different proportions and additives for the production of better absorbing dyes.

\section{Conclusions}

DSSCs have been fabricated using the highest conducting plasticized PVDF-HFP polymer electrolyte containing iodine/triiodide redox couple with $\mathrm{N} 3$, anthocyanin (from black rice extraction), and chlorophyll (from pandan extract) dyes as sensitizer. The DSSC using Ruthenizer 535 (N3) dye exhibits the best performance with a short-circuit current density of $8.16 \mathrm{~mA} \mathrm{~cm}^{-2}$, open-circuit voltage of $0.76 \mathrm{~V}$, fill factor of 0.35 , and the highest photoconversion efficiency of $2.2 \%$. As for the DSSC fabricated using natural dyes, the device with anthocyanin dye shows better performance compared to chlorophyll with a short-circuit current density of $1.07 \mathrm{~mA} \mathrm{~cm}^{-2}$, open-circuit voltage $0.43 \mathrm{~V}$, fill factor 0.33 , and efficiency of $0.2 \%$ under the illumination of
$100 \mathrm{~mW} \mathrm{~cm}^{-2}$ white light. However, the mixed dye system shows improved conversion efficiency suggesting that multidye mixtures may be more suitable for improving the efficiency of DSSCs.

\section{Acknowledgments}

The authors would like to thank University of Malaya for the financial support through Institute of Research Management and Consultancy of University Malaya, IPPP Grant (PS325/2009C) and (PS353/2009A) to carry out this research work. M. H. Buraidah and S. N. F. Yusuf thank the Ministry of Education Malaysia and University of Malaya for the scholarship and tutorship awarded, and M. M. Noor thanks the International Islamic University Malaysia (IIUM) for the study leave awarded.

\section{References}

[1] B. Li, L. Wang, B. Kang, P. Wang, and Y. Qiu, "Review of recent progress in solid-state dye-sensitized solar cells," Solar Energy Materials \& Solar Cells, vol. 90, no. 5, pp. 549-573, 2006.

[2] G. P. Smestad, "Education and solar conversion: demonstrating electron transfer," Solar Energy Materials \& Solar Cells, vol. 55, no. 1-2, pp. 157-178, 1998.

[3] P. Wang, S. M. Zakeeruddin, and M. Grätzel, "Solidifying liquid electrolytes with fluorine polymer and silica nanoparticles for quasi-solid dye-sensitized solar cells," Journal of Fluorine Chemistry, vol. 125, no. 8, pp. 1241-1245, 2004.

[4] Z. Liu, "Theoretical studies of natural pigments relevant to dye-sensitized solar cells," Journal of Molecular Structure: THEOCHEM, vol. 862, no. 1-3, pp. 44-48, 2008.

[5] J. Wu, Z. Lan, J. Lin, M. Huang, and P. Li, "Effect of solvents in liquid electrolyte on the photovoltaic performance of dyesensitized solar cells," Journal of Power Sources, vol. 173, no. 1, pp. 585-591, 2007.

[6] S. R. Scully, M. T. Lloyd, R. Herrera, E. P. Giannelis, and G. G. Malliaras, "Dye-sensitized solar cells employing a highly conductive and mechanically robust nanocomposite gel electrolyte," Synthetic Metals, vol. 144, no. 3, pp. 291-296, 2004.

[7] A. F. Nogueira, C. Longo, and M. A. De Paoli, "Polymers in dye sensitized solar cells: overview and perspectives," Coordination Chemistry Reviews, vol. 248, no. 13-14, pp. 1455-1468, 2004.

[8] D. W. Kim, Y. B. Jeong, S. H. Kim, D. Y. Lee, and J. S. Song, "Photovoltaic performance of dye-sensitized solar cell assembled with gel polymer electrolyte," Journal of Power Sources, vol. 149, no. 1-2, pp. 112-116, 2005.

[9] T. Asano, T. Kubo, and Y. Nishikitani, "Electrochemical properties of dye-sensitized solar cells fabricated with PVDFtype polymeric solid electrolytes," Journal of Photochemistry and Photobiology A, vol. 164, no. 1-3, pp. 111-115, 2004. 
[10] H. Chang, H. M. Wu, T. L. Chen, K. D. Huang, C. S. Jwo, and Y. J. Lo, "Dye-sensitized solar cell using natural dyes extracted from spinach and ipomoea," Journal of Alloys and Compounds, vol. 495, no. 2, pp. 606-610, 2010.

[11] A. O. T. Patrocínio, S. K. Mizoguchi, L. G. Paterno, C. G. Garcia, and N. Y. M. Iha, "Efficient and low cost devices for solar energy conversion: efficiency and stability of some naturaldye-sensitized solar cells," Synthetic Metals, vol. 159, no. 21-22, pp. 2342-2344, 2009.

[12] K. Wongcharee, V. Meeyoo, and S. Chavadej, "Dye-sensitized solar cell using natural dyes extracted from rosella and blue pea flowers," Solar Energy Materials \& Solar Cells, vol. 91, no. 7, pp. 566-571, 2007.

[13] S. Furukawa, H. Iino, T. Iwamoto, K. Kukita, and S. Yamauchi, "Characteristics of dye-sensitized solar cells using natural dye," Thin Solid Films, vol. 518, no. 2, pp. 526-529, 2009.

[14] B. Yuliarto, W. Septina, K. Fuadi, F. Fanani, L. Muliani, and Nugraha, "Synthesis of nanoporous $\mathrm{TiO}_{2}$ and its potential applicability for dye-sensitized solar cell using antocyanine black rice," Advances in Materials Science and Engineering, vol. 2010, Article ID 789541, 2010.

[15] Y. Amao, Y. Yamada, and K. Aoki, "Preparation and properties of dye-sensitized solar cell using chlorophyll derivative immobilized $\mathrm{TiO}_{2}$ film electrode," Journal of Photochemistry and Photobiology A, vol. 164, no. 1-3, pp. 47-51, 2004.

[16] H. Zhou, L. Wu, Y. Gao, and T. Ma, "Dye-sensitized solar cells using 20 natural dyes as sensitizers," Journal of Photochemistry and Photobiology A, vol. 219, no. 2-3, pp. 188-194, 2011.

[17] C. Sima, C. Grigoriu, and S. Antohe, "Comparison of the dye-sensitized solar cells performances based on transparent conductive ITO and FTO," Thin Solid Films, vol. 519, no. 2, pp. 595-597, 2010.

[18] D. Saikia, C. C. Han, and Y. W. Chen-Yang, "Influence of polymer concentration and dyes on photovoltaic performance of dye-sensitized solar cell with $\mathrm{P}(\mathrm{VdF}-\mathrm{HFP})$-based gel polymer electrolyte," Journal of Power Sources, vol. 185, no. 1, pp. 570576, 2008.

[19] Y. Ren, Z. Zhang, S. Fang, M. Yang, and S. Cai, "Application of PEO based gel network polymer electrolytes in dye-sensitized photoelectrochemical cells," Solar Energy Materials \& Solar Cells, vol. 71, no. 2, pp. 253-259, 2002.

[20] H. Yu, S. Zhang, H. Zhao, G. Will, and P. Liu, "An efficient and low-cost $\mathrm{TiO}_{2}$ compact layer for performance improvement of dye-sensitized solar cells," Electrochimica Acta, vol. 54, no. 4, pp. 1319-1324, 2009.

[21] Y. L. Lee, C. L. Chen, L. W. Chong, C. H. Chen, Y. F. Liu, and C. F. Chi, "A platinum counter electrode with high electrochemical activity and high transparency for dyesensitized solar cells," Electrochemistry Communications, vol. 12, no. 11, pp. 1662-1665, 2010.

[22] H. P. Singh and S. S. Sekhon, "Conductivity behaviour of proton conducting polymer gel electrolytes with PVdF-HFP," European Polymer Journal, vol. 39, no. 1, pp. 93-98, 2003.

[23] M. F. Z. Kadir, S. R. Majid, and A. K. Arof, "Plasticized chitosan-PVA blend polymer electrolyte based proton battery," Electrochimica Acta, vol. 55, no. 4, pp. 1475-1482, 2010.

[24] M. H. Buraidah, L. P. Teo, S. R. Majid, and A. K. Arof, "Ionic conductivity by correlated barrier hopping in NH4I doped chitosan solid electrolyte," Physica B, vol. 404, no. 8-11, pp. 1373-1379, 2009.

[25] S. Rajendran, M. Sivakumar, R. Subadevi, and M. Nirmala, "Characterization of PVA-PVdF based solid polymer blend electrolytes," Physica B, vol. 348, no. 1-4, pp. 73-78, 2004.
[26] V. C. Nogueira, C. Longo, A. F. Nogueira, M. A. Soto-Oviedo, and M. A. D. Paoli, "Solid-state dye-sensitized solar cell: improved performance and stability using a plasticized polymer electrolyte," Journal of Photochemistry and Photobiology A, vol. 181, no. 2-3, pp. 226-232, 2006.

[27] H. Chang and Y. J. Lo, "Pomegranate leaves and mulberry fruit as natural sensitizers for dye-sensitized solar cells," Solar Energy, vol. 84, no. 10, pp. 1833-1837, 2010. 


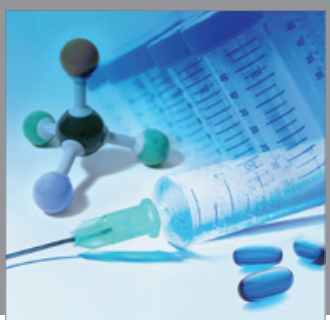

International Journal of

Medicinal Chemistry

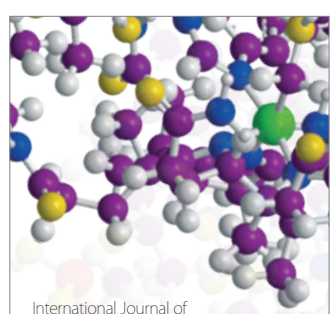

Carbohydrate Chemistry

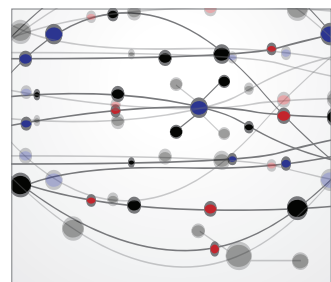

The Scientific World Journal
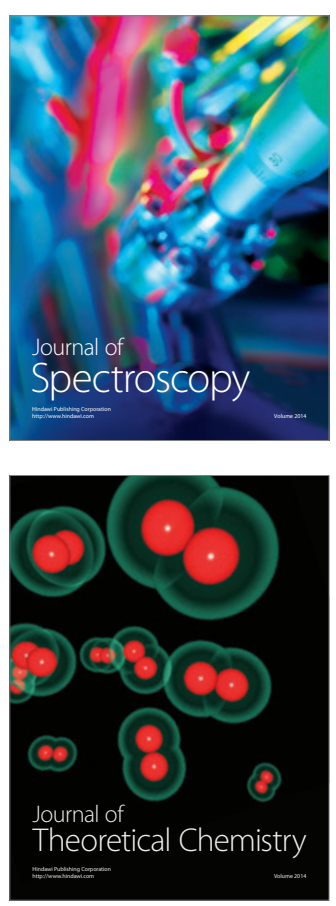
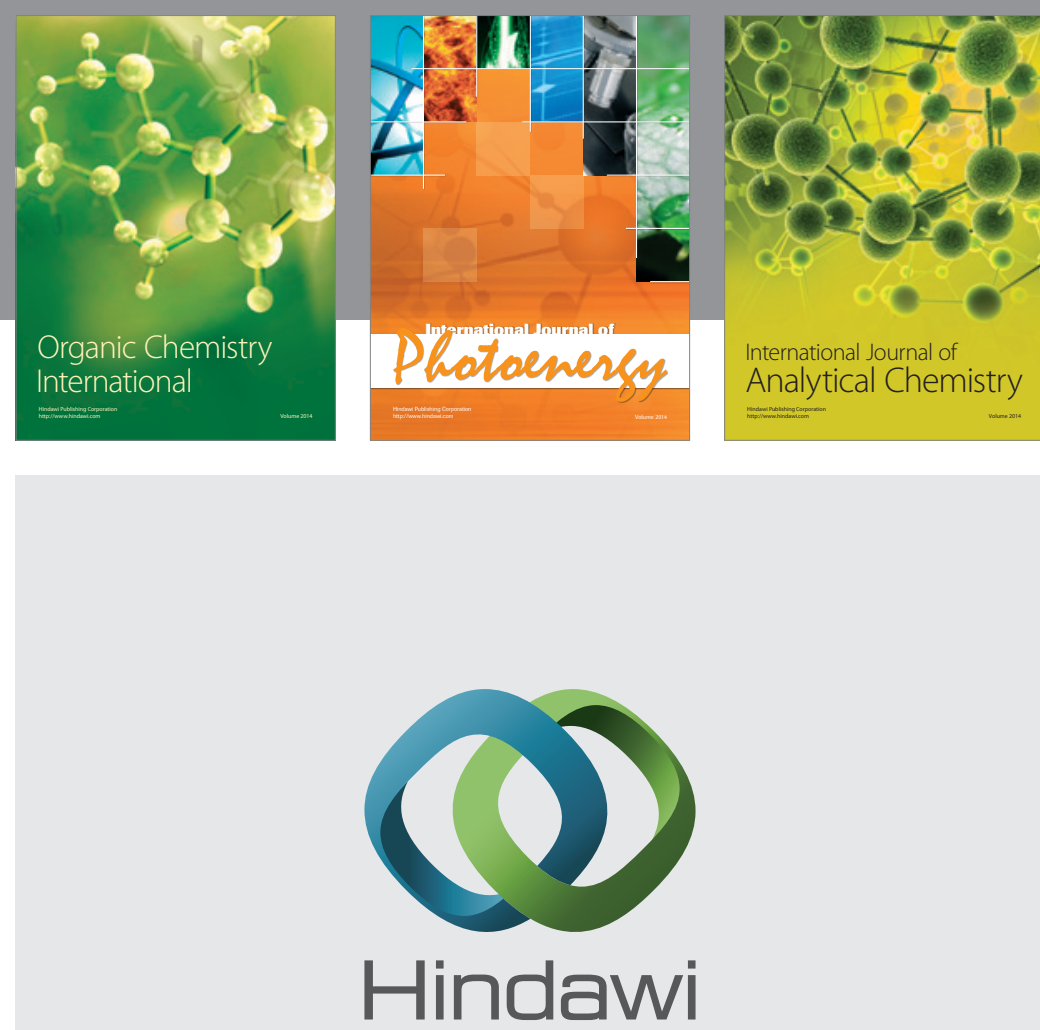

Submit your manuscripts at

http://www.hindawi.com
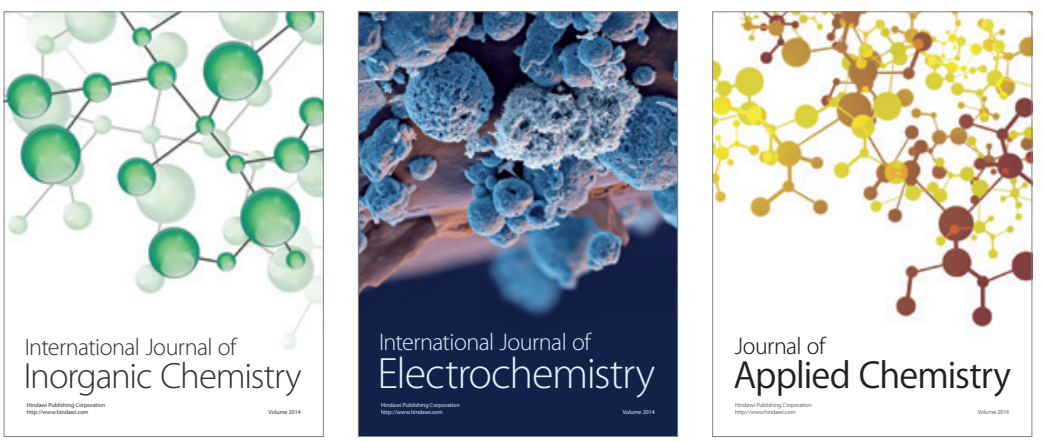

Journal of

Applied Chemistry
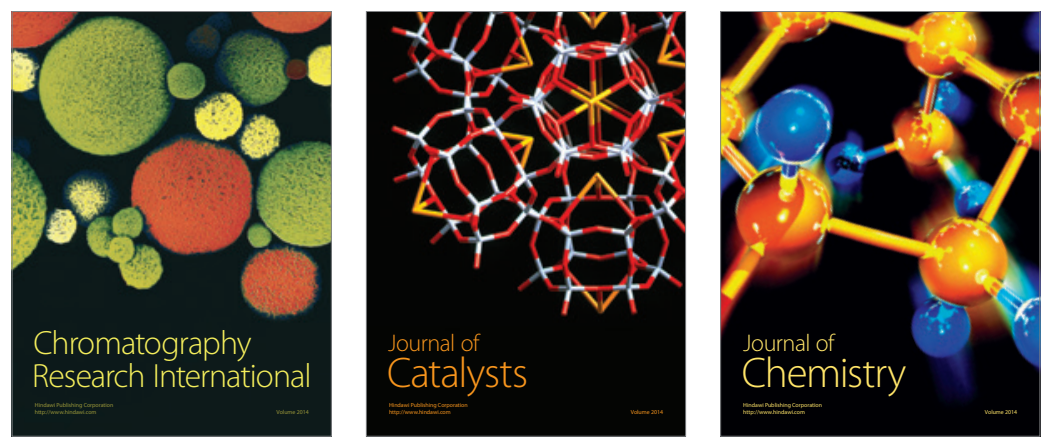
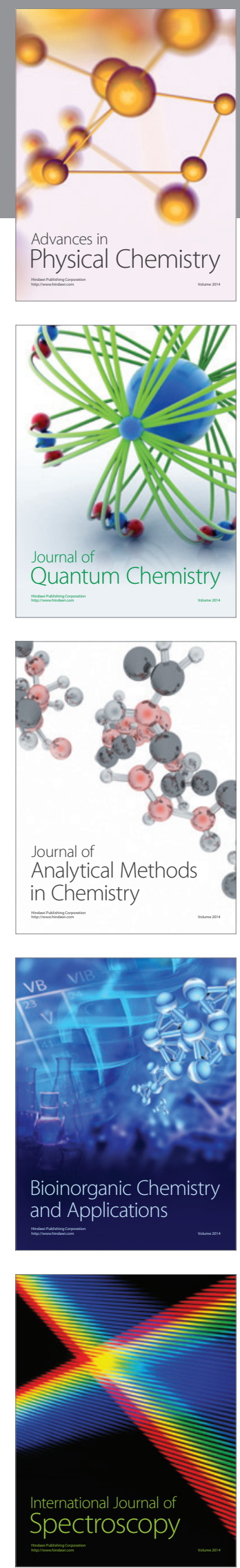